Bangladesh J. Zool. 42(2): 191-203, 2014

\title{
ACTIVITY PATTERNS OF PIED KINGFISHER (CERYLE RUDIS) AND STORK- BILLED KINGFISHER (PELARGOPSIS CAPENSIS) AT THE CHITTAGONG UNIVERSITY CAMPUS, BANGLADESH
}

\author{
J.K. Biswas*, N. J. Sarker ${ }^{1}$, M. F. Ahsan and M. M. Rahman \\ Department of Zoology, University of Chittagong, Chittagong-4331, Bangladesh
}

\begin{abstract}
The activity patterns of pied kingfisher (Ceryle rudis Linnaeus, 1758) and stork-billed kingfisher (Pelargopsis capensis Linnaeus, 1766) were studied in the Chittagong University Campus, Chittagong, Bangladesh, during January 2011 to December 2013. Eight activities (resting/perching, bathing, flying, feeding, calling, preening, hovering and diving) were observed in this study, of which pied kingfisher performed all eight activities and stork-billed kingfisher performed all except bathing and hovering. Both kingfisher species spent the maximum (pied kingfisher: 31.87\%; stork-billed kingfisher: 45.82\%) time in resting/perching and the minimum (pied kingfisher: 4.83\%; stork-billed kingfisher: $1.90 \%)$ in preening. Pied kingfishers were mostly $(28.3 \%)$ active during 0700 and $0900 \mathrm{~h}$ and stork- billed kingfishers were more $(31.17 \%)$ active in between 0901-1100 h. Pied kingfishers spent their highest (9.01\%) time in different activities in August and the lowest (7.68\%) in February, whereas storkbilled kingfishers spent the maximum (8.69\%) time in March and the minimum $(7.80 \%)$ in May.
\end{abstract}

Key words: Pied kingfisher, stork-billed kingfisher, activity pattern, time activity index.

\section{INTRODUCTION}

Pied kingfisher is a speckled, barred and black and white bird with the typical long, stout and dagger-shaped bill having black spots, and bands all over its body (Ali 1996), whereas stork-billed kingfisher is a beautiful freshwater swamp bird distinguished by its large size, blue wings and enormous blood-red dagger-shaped bill (Ali 1996, Ali and Ripley 1970, Islam and Kamruzzaman 2008). The several factors like habitat, weather and season usually influence the daily activity patterns of birds (Bull 1997, Yihune and Bekele 2010) and even the activity patterns also vary among the species (Blake 1992, Yihune and Bekele 2010). Information on the activity patterns of birds is particularly important for the occurrence of a particular activity that is, probably related to the energetic costs of their activities as well as this behaviour has a major manipulation on the evolution of foraging behaviour (Kacelnick and Houston 1984, Weimerskirch et al. 1997). The satellite telemetry (Jouventin and Weimerskirch 1990; Weimerskirch et al. 1997) has allocated the scope to workers to find out the

*Author for correspondence: <jadabbiswas@yahoo.com>. 1Department of Zoology, University of Dhaka, Dhaka-1000, Bangladesh. 
movement patterns and foraging array of different birds (Weimerskirch et al. 1997) and even the feeding time and size of prey can be verified with the stomach temperature's recorder (Wilson et al. 1992, Weimerskirch et al. 1997). The activity patterns of pied kingfishers (Ceryle spp.) were studied by few workers, but none study was recognized on the activity pattern of stork-billed kingfisher in Bangladesh and other countries in the world. Yihune and Bekele (2010) studied the diet and activities of pied kingfisher in Lake Hora Arsedi Debrezeit in Ethiopia, whereas Akhtar et al. (2007) reported the activity pattern of pied kingfisher (C. rudis) at Jahangirnagar University Campus (JUC), in Bangladesh. The present study was conducted to find out the daily activity patterns of pied kingfisher (Ceryle rudis) and stork-billed kingfisher (Pelargopsis capensis).

\section{MATERIAL AND METHODS}

Study area: The study was conducted from January 2011 to December 2013 in the eight different sites of the Chittagong University Campus (CUC): (1) Aquatic bodies close to the colony near Science Faculty Teacher Lounge to Botanical Garden, (2) Aquatic bodies of north side of the Shaheed Abdur Rab Hall to Lake near to the west side of Arts Faculty, (3) Aquatic bodies near Science Faculty to Institute of Marine Science, (4) Aquatic bodies near to the University Railway Station, (5) Aquatic bodies near to the west side of the Institute of Forestry and Environmental Science of Chittagong University (IFESCU), (6) Aquatic bodies close to the central Playground, (7) Katapahar and its adjacent areas, and (8) Shaheed Miner to Science Faculty Compound. The CUC is located at the village Fatepur under Hathazari upazila of Chittagong district in Bangladesh $\left(22^{\circ} 27^{\prime} 30^{\prime \prime}\right.$ ' and $22^{\circ} 29^{\prime} 0^{\prime \prime}$ ' North Latitudes to $91^{\circ} 46^{\prime} 30^{\prime \prime}$ and $91^{\circ} 47^{\prime} 45^{\prime \prime}$ East Longitudes). It is about $22 \mathrm{~km}$ north of the Chittagong city and $3 \mathrm{~km}$ south west of Hathazari upazila headquarter and connected with the highway road of Chittagong-Rangamati (Ahsan and Khanom 2005).

Equipments: One pair of binoculars (Bushnell, $90 \times 90 ; 140 \mathrm{M} / 2000 \mathrm{M}$ ) was used to observe different activities (resting/perching, bathing, flying, feeding, calling, preening, hovering and diving) of two kingfisher species. A field guide book (Grimmett et al. 1999) was also used to identify the study species (pied kingfisher and stork-billed kingfisher) and other bird species during the study period. On the other hand, one camera (Nikon COOLPIX, P 520; 42X optical zoom, 18.1 megapixel) was utilised to get the photographs of different activities of the study species. One stopwatch was also used to record the duration of activity patterns performed by pied and stork-billed kingfisher in the study area. 
Observation techniques: The kingfishers have a schedule depending on the time of a day that always keeps them busy and active. Activity patterns of the kingfishers were recorded in respect to the percentages of time spent in different activities. The study species were observed based on two-hour time block from 0700 to $1900 \mathrm{~h}$ during summer, whereas 0700 to $1730 \mathrm{~h}$ in winter season depending on the sunlight of the day. The data of activity patterns were recorded based on 5-minute intervals by using focal animal sampling and scan sampling methods followed by Altmann (1974). The daily activities were noted and calculated for each hour, day and month.

The time-activity index (TAI) was determined in favour of both species by using the following formula:

TAI $(\%)=$ TTA $\times 100 /$ TDO $($ Morrier and McNeil 1991, Borah 2011)

Here, TTA = total time (s) spent in a particular activity during the surveillance period, and $\mathrm{TDO}=$ total duration of observation used for the species.

The following eight major activities were recorded.

(a) Resting/perching: An upright posture on any substratum.

(b) Bathing: The continuous diving for several times from a definite height, and preened and rubbed the body.

(c) Flying: Birds were on the wings around their fishing ground.

(d) Feeding: Consuming the prey into their mouth and buccal cavity.

(e) Calling: The time when kingfisher making sound actively.

(f) Preening: All comfort activities like feather trembling, wing waving, bill cleaning, and body and tail shaking.

(g) Hovering: When a bird leaves the perch and gradually flies to lower and lower heights until it finally plunges into the water to pierce the prey.

(h) Diving: When the birds dived for once or twice but did not rub and preen the body.

\section{RESULTS AND DISCUSSION}

Overall activity patterns and Time-activity index (TAI): Eight activities (resting, bathing, flying, feeding, calling, preening, hovering and diving) of pied kingfisher were observed, whereas six activities of stork-billed kingfisher (resting, flying, feeding, calling, preening and diving) were recorded during the study period (Table 1). Yihune and Bekele (2010) described eight major activities (perching, feeding, calling, flying, hovering, scanning, diving and preening) for pied kingfisher both in dry and wet seasons in Lake Hora-Arsedi of Debrezeit, 


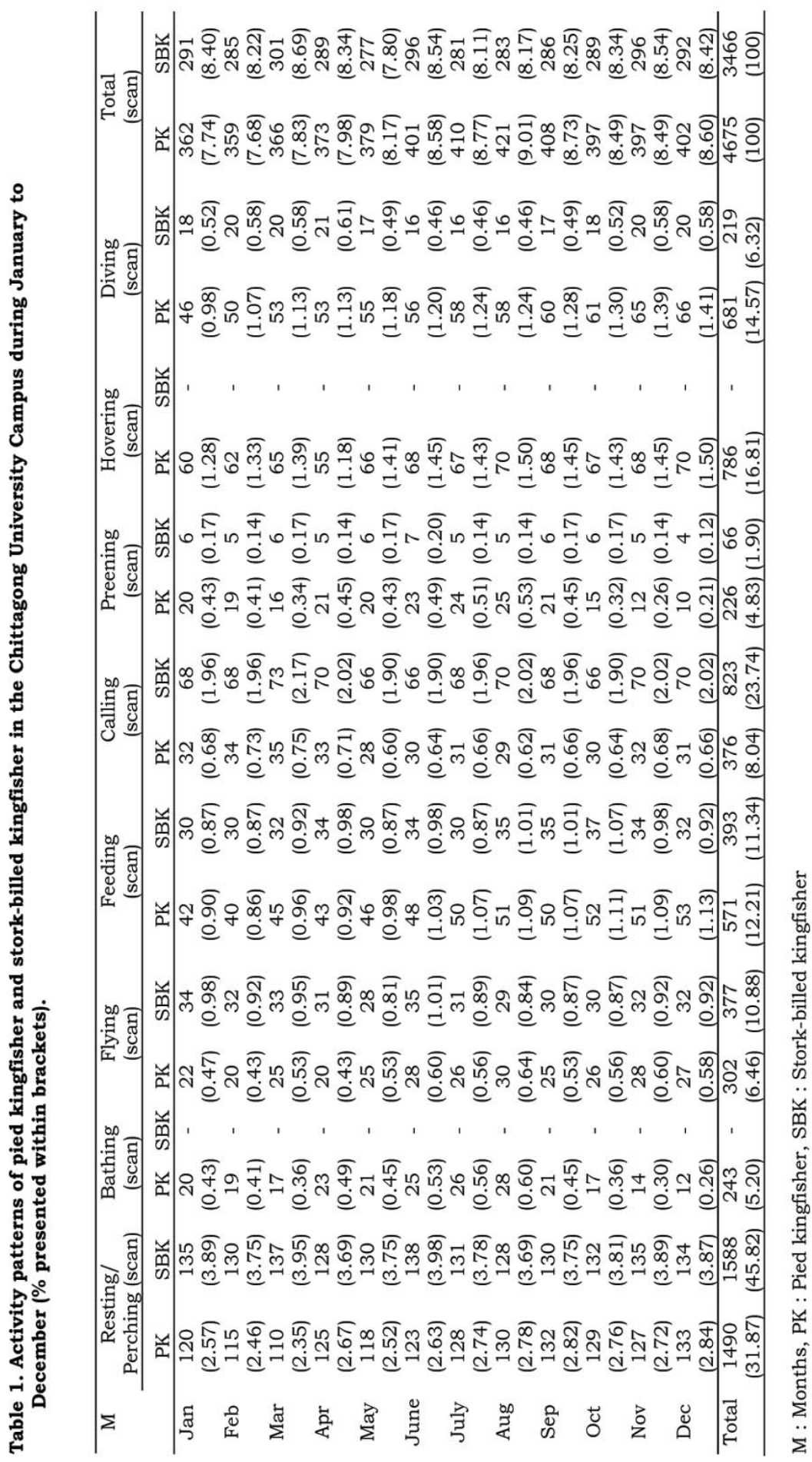


Ethiopia; while Akhtar et al. (2007) mentioned six main activities (foraging, feeding, resting, flying, calling and preening) of pied kingfisher from the Jahangirnagar University Campus (JUC), Bangladesh. On the other hand, Naher (2012) reported five most important activities (resting, bathing, diving, preening and calling) for common kingfisher (Alcedo atthis) and white-throated kingfisher (Halcyon smyrnensis) in Bangladesh.

A total of 4,675 scan samples (389.58 hours) were recorded for pied kingfishers of which they spent the highest time (7,459 min; TAI: $31.87 \%)$ in resting/perching and the lowest (1,130 min; TAI: 4.83\%) in preening; while 3,466 scans ( 288.83 hours) were recorded for stork-billed kingfisher where they also spent the maximum time (7,940 min; TAI: $45.82 \%)$ in resting/perching and the minimum (330 min; TAI: 1.90\%) in preening (Tables $1 \& 2$ ) that differed significantly between two kingfisher species (min: $\mathrm{F}=5.704297$, df $=7, \mathrm{p}=$ 0.017568; TAI: $\mathrm{F}=4.356499, \mathrm{df}=7, \mathrm{p}=0.035474)$. On the other hand, the activity patterns and the time used (TAI) by pied and stork-billed kingfishers individually in different activities also varied significantly within species (pied kingfisher: $\mathrm{t}=3.93, \mathrm{df}=7, \mathrm{p}=0.005$; stork-billed kingfisher: $\mathrm{t}=2.54$, $\mathrm{df}=5, \mathrm{p}=$ 0.05).

Yihune and Bekele (2010) observed that pied kingfisher spent the highest $(21.27 \%)$ time in perching and the lowest $(6.24 \%)$ in preening during the dry season, whereas the maximum (35.4\%) time in perching and the minimum $(3.3 \%)$ in hovering during the wet season. Akhtar et al. (2007) reported that pied kingfisher spent the maximum time of their active day period in resting (34.76\%) whereas $29.79 \%$ time in both foraging and feeding, $12.55 \%$ in flying, $11.55 \%$ in calling and $11.35 \%$ in different social activities in the JUC, Bangladesh.

Overall daily activity patterns: The overall daily activity patterns between two kingfisher species at different time blocks were not similar and these varied significantly $(\mathrm{F}=12.65947, \mathrm{df}=5, \mathrm{p}=0.007269)$. Pied kingfishers were more (28.3\%) active during 0700-0900 $\mathrm{h}$ and less (3.77\%) in 1301-1500 $\mathrm{h}$ that varied significantly $(\mathrm{t}=4.26$, $\mathrm{df}=5, \mathrm{p}=0.008)$, while stork-billed kingfishers were mostly (31.17\%) active during 0901-1100 $\mathrm{h}$ and least $(1.96 \%)$ in $1701-1900 \mathrm{~h}$ that also differed significantly $(\mathrm{t}=3.66, \mathrm{df}=5, \mathrm{p}=0.01)$ (Fig. 1). Akhtar et al. (2007) described two major activities (feeding and resting) during the day period, of which the highest (10.13\%) feeding was observed at $0600 \mathrm{~h}$ and the maximum $(11.20 \%)$ resting was at $1300 \mathrm{~h}$ in the JUC, Bangladesh.

Overall monthly and seasonal activity patterns: Pied kingfisher spent the highest time (9.01\%) in August and the lowest (7.68\%) in February but storkbilled kingfishers spent the maximum time (8.69\%) in March and the minimum $(7.80 \%)$ in May (Table 1$)$, which did not differ significantly $(F=0.755827$, df $=$ 
$11, \mathrm{p}=0.67476)$. On the other hand, pied kingfishers were more $(34.99 \%)$ active in rainy season and less $(32.49 \%)$ in summer, whereas stork-billed kingfishers were most (33.58\%) active in winter and least $(32.87 \%)$ active in rainy season (Fig. 2) that did not vary significantly between two species $(\mathrm{F}=0.374023$, df $=2$, $\mathrm{p}=0.72779$ ).

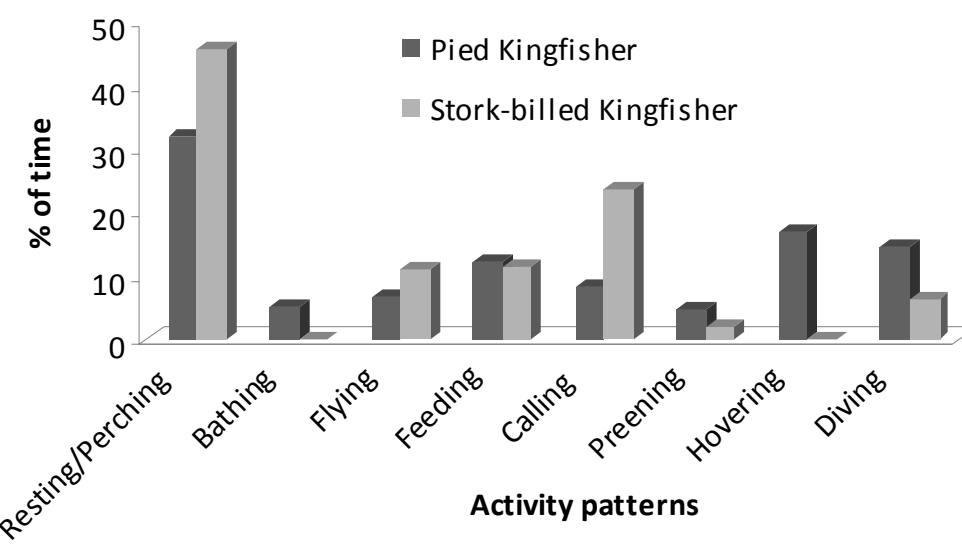

Fig. 1. Overall activity patterns of two kingfisher species in different hours in the Chittagong University Campus.

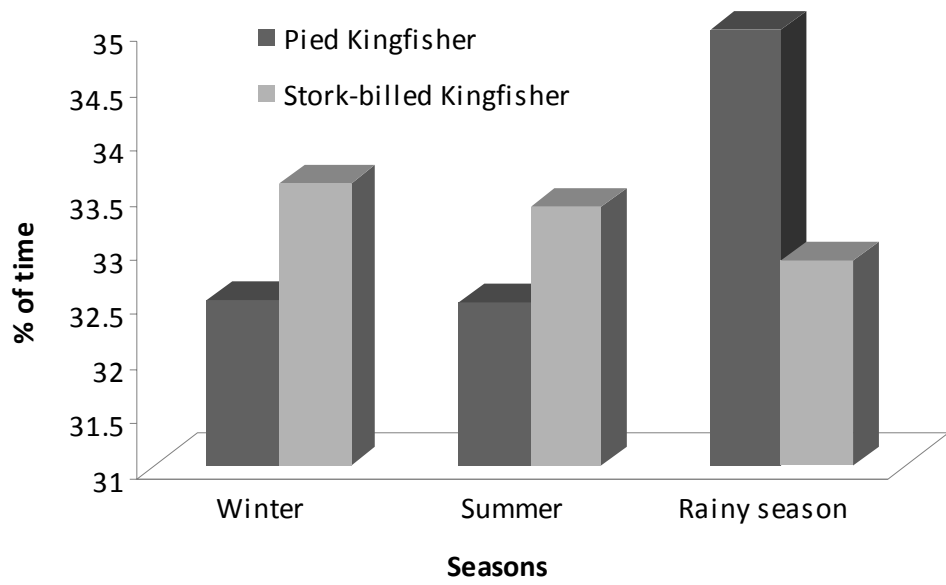

Fig. 2. Overall activity patterns of two kingfishere species in different seasons in the Chittagong University Campus.

Resting/perching: Both kingfisher species spent the maximum time in resting/perching at 1301-1500 $\mathrm{h}$ (pied kingfisher: 30.43\%; stork-billed kingfisher: $33.33 \%$ ) and the minimum at both 0901-1100 $\mathrm{h}$ and 1701-1900 $\mathrm{h}$ 
(pied kingfisher: 8.7\%; stork-billed kingfisher: 8.33\%) (Fig. 3), which differed significantly between two kingfishers $(F=33.70537, \mathrm{df}=5, \mathrm{p}=0.000742)$. Akhtar et al. (2007) reported that pied kingfisher spent the highest time $(11.20 \%)$ in resting at $1300 \mathrm{~h}$ and the lowest $(3.77 \%)$ at $0600 \mathrm{~h}$ in the JUC, Bangladesh. Naher (2012) observed the maximum resting activities of common kingfisher and white-throated kingfisher at midday (common kingfisher: 1201$1300 \mathrm{~h}$ and 1401-1500 h; white-throated kingfisher: 1301-1400 h).

On the other hand, pied kingfisher spent the maximum $(2.84 \%)$ time in resting/perching in December and the minimum $(2.35 \%)$ in March, but storkbilled kingfishers spent the highest (3.98\%) time resting in June and the lowest (3.69\%) both in April and August (Table 1), which did not vary significantly between two kingfishers $(\mathrm{F}=0.588205, \mathrm{df}=11, \mathrm{p}=0.803844)$. Akhtar et al. (2007) observed that pied kingfisher spent the maximum time $(44.12 \%)$ in September and the minimum $(25.00 \%)$ in October in the JUC. In addition, the resting/perching activity patterns of two kingfishers were almost similar in different seasons and it did not vary significantly $(\mathrm{F}=0.338986$, $\mathrm{df}=2, \mathrm{p}=$ 0.746834). Pied kingfisher spent the highest (34.83\%) time in resting/perching during rainy season and the lowest $(31.95 \%)$ in summer, but stork-billed kingfisher spent the maximum (33.63\%) time in resting/perching during winter and the minimum $(32.81 \%)$ in rainy season (Fig. 4). Naher (2012) observed that both of the species (common and white-throated kingfishers) spent the maximum time in resting in winter and the minimum in rainy season.

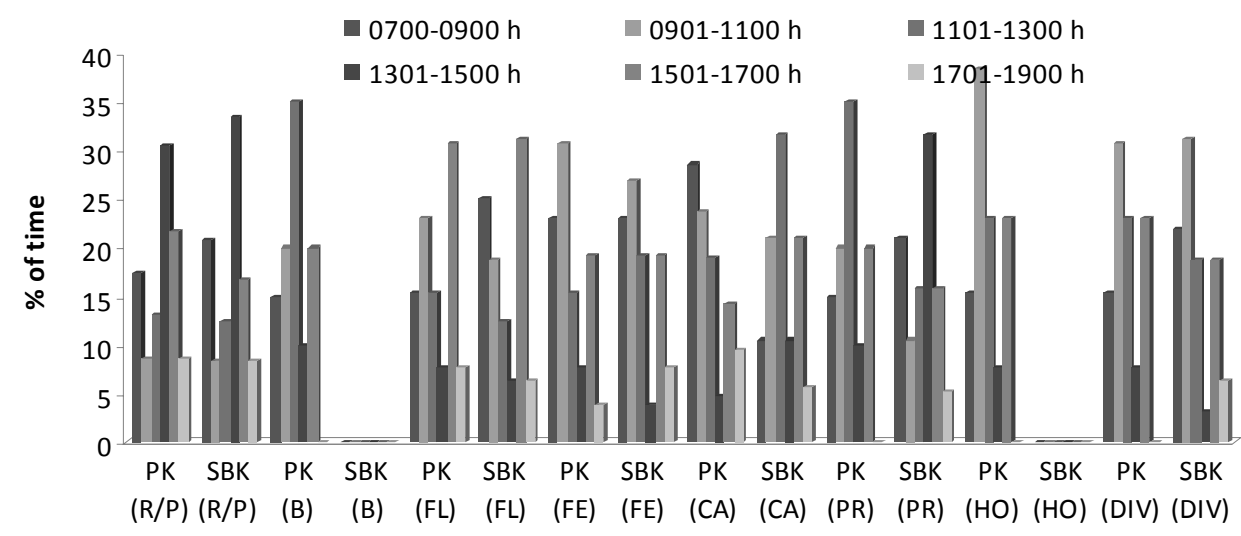

Activity patterns of both kingfishers

PK: Pied Kingfisher, SBK: Stork-billed Kingfsiher, R/P: Resting/Perching, B: Bathing, FL: Flying, FE: Feeding, CA: Calling, PR: Preening, HO: Hovering and DIV: Diving.

Fig. 3. Activity patterns of both kingfisher species in different day time blocks in the Chittagong University Campus. 
Bathing: Bathing activity was observed only in pied kingfisher. They used the highest $(35.00 \%)$ time in bathing at $1101-1300 \mathrm{~h}$ and the lowest $(00 \%)$ at 1701 $1900 \mathrm{~h}$ (Fig. 3), which differed significantly $(\mathrm{t}=3.49, \mathrm{df}=5, \mathrm{p}=0.01)$. Besides, pied kingfishers spent the maximum $(0.56 \%)$ time in bathing in July and the minimum $(0.26 \%)$ in December (Table 1$)$ that varied significantly among monthly $(\mathrm{t}=14.16, \mathrm{df}=11, \mathrm{p}=1.50 \mathrm{E}-08)$, whereas they used the highest $(37.86 \%)$ time during rainy season and the lowest $(26.75 \%)$ in winter (Fig. 4), which also varied significantly among season $(t=9.90, d f=2, p=0.01)$. Naher (2012) reported that common kingfisher and white-throated kingfisher preferred 1201-1300 $\mathrm{h}$ for bathing once in a day, $1100-1200 \mathrm{~h}$ and 1501-1600 $\mathrm{h}$ for twice in a day, while $0901-1000 \mathrm{~h}, 1101-1300 \mathrm{~h}$ and $1501-1700 \mathrm{~h}$ for thrice in a day. Bathing activity was the highest in December and the lowest during June to August for common kingfisher, whereas white-throated kingfisher spent the maximum time in bathing in November and December, and the minimum from February to July (op. cit.).

Flying: The flying activity was more prominent $(10.88 \%)$ in stork-billed kingfisher than that of pied kingfisher (6.46\%) (Table 1) and it was not similar between the two kingfisher species in different day periods and it differed significantly $(F=13.91628, d f=5, p=0.005874)$. Both kingfisher species spent the maximum time in flying at 1501-1700 $\mathrm{h}$ (pied kingfisher: $30.77 \%$; storkbilled kingfisher: 31.25\%) and the minimum at both 1301-1500 $\mathrm{h}$ and 17011900 h (pied kingfisher: 7.7\%; stork-billed kingfisher: 6.25\%) (Fig. 3). Akhtar et al. (2007) observed the maximum flying (11.76\%) activity of pied kingfishers at $0600 \mathrm{~h}$ and the minimum at $1300 \mathrm{~h}$ during their active daytime in the JUC.

On the other hand, flying activity was maximum (0.64\%) in August and minimum (0.43\%) both in February and April for pied kingfisher, whereas it was the highest $(1.01 \%)$ in June and minimum $(0.81 \%)$ in May for stork-billed kingfisher (Table 1) that did not differ significantly between two species among months $(\mathrm{F}=0.823662, \mathrm{df}=11, \mathrm{p}=0.623333)$. Akhtar et al. (2007) observed that pied kingfisher spent the highest time (15.29\%) in flying in October and the lowest (8.68\%) in August in the JUC. In addition, pied kingfisher spent the maximum (35.43\%) time in flying in rainy season and the minimum $(32.12 \%)$ in winter, whereas stork-billed kingfisher used the highest (34.48\%) time in flying during winter and the lowest (31.83\%) in rainy seasons (Fig. 4), which did not differ significantly between two species $(\mathrm{F}=0.031587, \mathrm{df}=2, \mathrm{p}=0.96938)$.

Feeding: Pied kingfishers were most active (30.77\%) in feeding at 0901-1100 $\mathrm{h}$ and least (3.85\%) at 1701-1900 h, whereas stork-billed kingfishers spent the maximum $(26.92 \%)$ time in feeding at $0901-1100 \mathrm{~h}$ and the minimum $(3.85 \%)$ at 1301-1500 h (Fig. 3), which was not similar between two kingfishers and varied 
significantly $(\mathrm{F}=29.30343, \mathrm{df}=5, \mathrm{p}=0.001037)$. Besides, pied kingfishers spent the highest $(1.13 \%)$ time in feeding in December and the lowest $(0.86 \%)$ in February, whereas stork-billed kingfishers expended the maximum (1.07\%) time in feeding in October and the minimum $(0.87 \%)$ in January, February, May and July (Table 1$)$, which varied significantly between two species $(F=3.232454$, df $=11, \mathrm{p}=0.031981)$. Akhtar et al. (2007) reported that pied kingfisher spent the highest $(40.43 \%)$ time in feeding and foraging in October the lowest $(24.33 \%)$ in September in the JUC, Bangladesh.

In addition, pied kingfisher spent the maximum $(35.55 \%)$ time in feeding during winter and the minimum (31.87\%) in summer, whereas stork-billed kingfisher used the most $(34.86 \%)$ time in feeding during rainy season and the least $(32.06 \%)$ in winter (Fig. 4), which was approximately similar and did not differ significantly between two species $(\mathrm{F}=9.59314, \mathrm{df}=2, \mathrm{p}=0.094401)$.

Calling: Pied kingfishers were more (28.57\%) active in calling at $0700-0900$ $\mathrm{h}$ and less $(4.76 \%)$ at $1301-1500 \mathrm{~h}$, whereas stork-billed kingfishers spent the maximum (31.58\%) time in calling at $1101-1300 \mathrm{~h}$ and the minimum $(5.62 \%)$ at 1701-1900 h (Fig. 3), which was approximately similar and did not differ significantly between two kingfisher species in day hours $(F=1.92705$, df $=5, p$ $=0.24444)$. Akhtar et al. (2007) recorded the highest (9.09\%) calling activities of pied kingfisher between $0600 \mathrm{~h}$ and $0700 \mathrm{~h}$. Naher (2012) reported the highest calling at 0800-0900 $\mathrm{h}$ for common kingfisher and 1000-1100 $\mathrm{h}$ for whitethroated kingfisher during flying, whereas the maximum calling at 1000-1100 $\mathrm{h}$ for common kingfisher and 1100-1200 $\mathrm{h}$ for white-throated kingfisher during resting.

Besides, pied kingfishers spent more $(0.75 \%)$ time in calling in March and the less $(0.60 \%)$ in May, while stork-billed kingfishers spent the maximum $(2.17 \%)$ time in calling in March and the minimum $(1.90 \%)$ in May, June and October (Table 1), which varied significantly between two species in different months $(\mathrm{F}=3.686691$, $\mathrm{df}=11, \mathrm{p}=0.020274)$. Akhtar et al. (2007) described that pied kingfisher spent the maximum time (14.08\%) in October and the minimum $(7.49 \%)$ in September. The highest calling activity was recorded in November for common kingfisher and February for white-throated kingfisher during flying; whereas common kingfisher spent the highest time in calling in December and white-throated kingfisher in February during resting (Naher 2012).

In addition, both pied and stork-billed kingfishers spent respectively the highest time (34.31\% and 33.54\%) in calling during the winter and the lowest $(32.18 \%$ and $33.05 \%)$ in rainy seasons (Fig. 4); which was almost similar and did not differ significantly between the two species in different seasons $(\mathrm{F}=$ 
2.594842, $\mathrm{df}=2, \mathrm{p}=0.278176)$. Common kingfisher spent the maximum time in calling in winter and the minimum in monsoon, while white-throated kingfisher spent the highest time in calling in winter during flying (Naher 2012). On the other hand, the highest calling was recorded in summer and the lowest in winter for common kingfisher during resting, whereas white-throated kingfisher spent the highest time in calling in winter (op. cit.).

Preening: The preening activity was approximately similar in two species and did not vary significantly between the them in different day time blocks $(\mathrm{F}=$ 1.174617 , df $=5, \mathrm{p}=0.432061$ ) (Table 1). Pied kingfishers spent the maximum $(35.00 \%)$ time in preening at $1101-1300 \mathrm{~h}$ and the minimum $(00 \%)$ during 1701 $1900 \mathrm{~h}$, whereas stork-billed kingfishers used the highest (31.58\%) time during 1301-1500 $\mathrm{h}$ and the lowest (5.16\%) at 1701-1900 h (Fig. 3). On the other hand, pied kingfisher spent the maximum time $(0.53 \%)$ in preening in August and the minimum $(0.21 \%)$ in December; whereas stork-billed kingfisher exercised the highest time in preening in June $(0.20 \%$ and the minimum in December $(0.12 \%)$ (Table 1), that did not differ significantly between two species in different months $(\mathrm{F}=1.314678, \mathrm{df}=11, \mathrm{p}=0.328938)$. In addition, pied kingfishers spent the highest $(37.61 \%)$ time in preening in rainy season and the lowest $(26.99 \%)$ in winter, whereas stork-billed kingfishers used the maximum (36.36\%) time during summer and the minimum (30.30\%) in winter (Fig. 4); which was almost similar and did not vary significantly between the two kingfishers in different seasons $(\mathrm{F}=4.375579, \mathrm{df}=2, \mathrm{p}=0.186026)$.

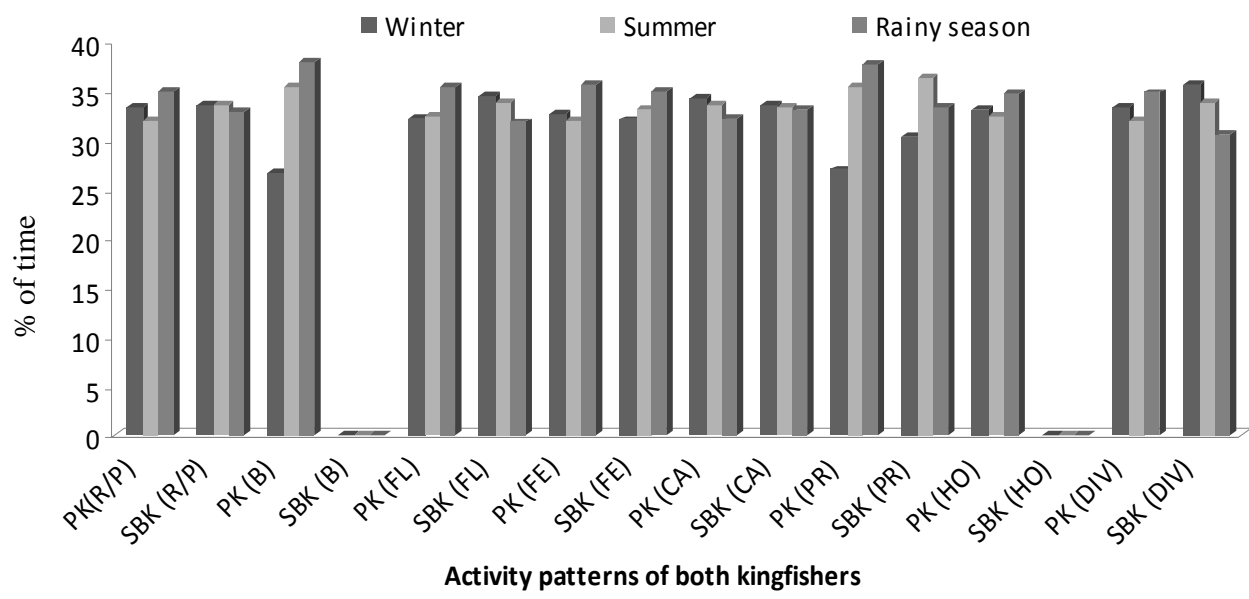

PK: Pied Kingfisher, SBK: Stork-billed Kingfsiher, R/P: Resting/Perching, B: Bathing, FL: Flying, FE: Feeding, CA: Calling, PR: Preening, HO: Hovering and DIV: Diving.

Fig. 4. Activity patterns of both kingfisher species in different seasons in the Chittagong University Campus. 
Akhtar et al. (2007) described two types (self and social) of preening activities of pied kingfisher in the JUC of which self preening was $64.17 \%$ and social preening was $35.83 \%$. Self preening of pied kingfisher was observed maximum $(79.25 \%)$ in September and minimum $(52.27 \%)$ in January; whereas social preening was the highest $(47.13 \%)$ in January and the lowest $(20.17 \%)$ in September (op. cit.). Naher (2012) recorded the highest preening activity at 0700 - $0800 \mathrm{~h}$ for common kingfisher and 1500-1600 $\mathrm{h}$ for white-throated kingfisher. On the other hand, common kingfisher spent the highest time in preening in September and the lowest in June while white-throated kingfisher spent the maximum time in preening in August and the minimum in May (op. cit.). In addition, both species exercised the highest time in preening during winter and the lowest in summer (op. cit.).

Hovering: Among the daily activity patterns, stork-billed kingfishers did not perform hovering; whereas pied kingfishers spent the maximum (38.46\%) time in hovering at 0901-1100 $\mathrm{h}$ and the minimum (00\%) at 1701-1900 h (Fig. 3); which varied significantly in different hours of the day $(\mathrm{t}=3.26$, df $=5, \mathrm{p}=$ 0.02). On the other hand, pied kingfisher used the highest $(1.5 \%)$ time in hovering in August and December, and the lowest (1.18\%) in April (Table 1), that varied significantly in different months $(\mathrm{t}=51.59, \mathrm{df}=11, \mathrm{p}=1.78 \mathrm{E}-14)$; whereas they spent the maximum (34.61\%) time during the rainy season and the minimum $(32.32 \%)$ in summer (Fig. 4) which also varied significantly in different seasons $(\mathrm{t}=49.50, \mathrm{df}=2, \mathrm{p}=0.0004)$.

Table 2. Total time activy index (TAI) of pied kingfisher and stork-billed kingfisher in the Chittagong University Campus.

\begin{tabular}{lcccccc}
\hline \multirow{2}{*}{ Activities } & \multicolumn{2}{c}{ TTA $^{1}$ (Min) } & \multicolumn{2}{c}{ TDO $^{2}$ (Min) } & \multicolumn{2}{c}{ TAI (\%) } \\
\cline { 2 - 7 } & PK & SBK & PK & SBK & PK & SBK \\
\hline Resting / perching & 7450 & 7940 & 23375 & 17330 & 31.87 & 45.82 \\
Bathing & 1215 & 00 & 23375 & 17330 & 5.20 & 00 \\
Flying & 1510 & 1885 & 23375 & 17330 & 6.46 & 10.88 \\
Feeding & 2855 & 1965 & 23375 & 17330 & 12.21 & 11.34 \\
Calling & 1880 & 4115 & 23375 & 17330 & 8.04 & 23.74 \\
Preening & 1130 & 330 & 23375 & 17330 & 4.83 & 1.90 \\
Hovering & 3930 & 00 & 23375 & 17330 & 16.61 & 00 \\
Diving & 3405 & 1095 & 23375 & 17330 & 14.57 & 6.32 \\
\hline
\end{tabular}

1 TTA: Total time spent in a particular activity during the observation period; 2 TDO: Total duration observation used for the species; SBK: Stork-billed Kingfisher; PK : Pied Kingfsiher.

Diving: The diving activity was not same between the two kingfishers and it varied significantly $(\mathrm{F}=15.88442, \mathrm{df}=5, \mathrm{p}=0.004347)$ in different day periods. Pied kingfishers used the highest (30.77\%) time in diving at 0901-1100 $\mathrm{h}$ and the lowest $(00 \%)$ at $1701-1900 \mathrm{~h}$, whereas stork-billed kingfishers spent the maximum $(31.25 \%)$ time at $0901-1100 \mathrm{~h}$ and the minimum $(3.13 \%)$ at 1301 - 
$1500 \mathrm{~h}$ (Fig. 3). On the other hand, pied kingfishers used maximum time $(1.41 \%)$ in diving in December and minimum (0.98\%) in January; whereas storkbilled kingfishers spent the highest time $(0.61 \%)$ in April and the lowest $(0.46 \%)$ during June to August (Table 1), that did not differ significantly between two species in different months $(\mathrm{F}=0.961774$, $\mathrm{df}=11, \mathrm{p}=0.525189)$. In addition, pied kingfishers spent the highest $(34.80 \%)$ time in diving in rainy season and the lowest $(31.89 \%)$ in summer, whereas stork-billed kingfishers utilised the maximum (35.62\%) time during winter and the minimum $(30.59 \%)$ in rainy season (Fig. 4), which was almost similar and did not differ significantly between the two kingfishers in different seasons $(F=0.29411$, df $=2, p=0.772732)$. Naher (2012) recorded the highest diving frequency at 1100-1200 $\mathrm{h}$ for common kingfisher, while 1500-1600 h for white-throated kingfisher. Both the species (common kingfisher and white-throated kingfisher) spent maximum time in diving in November; but common kingfisher spent the minimum time in diving during February to March and white-throated kingfisher in February (op. cit.). On the other hand, common kingfisher and white-throated kingfisher spent the highest time in diving in winter (op. cit.).

Diving and success: A total of 681 scan samples of diving were recorded pied kingfishers, whereas 291 scan samples for stork-billed kingfishers during the study period. The average success rate was $(77.97 \%)$ in pied kingfishers and $(72.16 \%)$ in stork-billed kingfishers.

Daily activities are important behavioural patterns of a bird. Pied kingfisher is a common and stork-billed kingfisher is an uncommon resident birds in Bangladeh, but the population of these two kingfisher species is gradually decling due to anthropogenic factors. Therfore, such behavioural study may help to know their life history and to take initiative for conserving them in constricted nature of Bangladesh.

\section{LITERATURE CITED}

AHSAN, M. F. and KHANOM, N. 2005. Birds of the Chittagong University Campus, Chittagong. The Chittagong Univ. J. Sci. 29(1): 77-88.

AKHTAR, S., KABIR, M. M., HASAN, M. K. and BEGUM, S. 2007. Activity pattern of pied kingfisher (Ceryle rudis) at Jahangirnagar University campus. Bangladesh J. Life Sci. 19(1): 49-58.

ALI, S. 1996. The book of Indian Birds. Twelfth Revised and Enlarged edition. Bombay Natural History Society, Oxford University Press, Mumbai. 354 pp.

ALI, S. and RIPLEY, S. D. 1970. Handbook of the birds of India and Pakistan. Oxford Univ. Press, Bombay, London, New York. Vol. 4: 263 pp.

ALTMANN, J. 1974. Observational study of behaviour: sampling method. Behav. 49: 222-267.

BLAKE, J. G. 1992. Temporal variation in point counts of birds in a lowland wet forest in Costa Rica. Condor. 94: 265-275. 
BORAH, J. 2011. Occupancy pattern and food-niche partitioning among sympatric kingfishers in Bhitarkanika mangroves, Orissa. Unpublished M.S. (Wildlife Science) thesis. Wildlife Institute of India. $61 \mathrm{pp}$.

BULL, W. 1997. Daily variation in activity and flock size of two parakeet species from Southeastern Brazil. Short Comm. 109: 343-348.

GRIMMETT, R., INSKIP, C. and INSKIP, T. 1999. Pocket guide to the birds of the Indian Subcontinent. Oxford Univ. Press, New Delhi, India. 384 pp.

ISLAM, M. A. and KAMRUZZAMAN, M. 2008. Pelargopsis capensis. pp. 73-74. In: Siddiqui, K.U., Islam, M. A., Kabir, S. M. H., Ahmed, M., Ahmed, A. T. A., Rahman, A. K. A., Haque, E. U., Ahmed, Z. U., Begum, Z. N. T., Hassan, M. A., Khondker, M. and Rahman, M. M. (eds.) 2008. Encyclopedia of flora and fauna of Bangladesh, vol. 26. Birds. Asiatic Society of Bangladesh. Dhaka. 662 pp.

JOUVENTIN, P. and WEIMERSKIRCH, H. 1990. Satellite tracking of wandering albatrosses. Nature. 343: 746-748.

KACELNICK, A. and HOUSTON, A. 1984. Some effects of energy costs on foraging strategies. Anim. Behav. 32: 609-614.

MORRIER, A., and MCNEIL, R. 1991. Time-activity budget of Wilson's and Semipalmated plovers in a tropical environment. The Wilson Bulletin. 598-620.

NAHER, H. 2012 Food habits, breeding biology and conservation issues of Kingfishers, Alcedo atthis and Halcyon smyrnensis. Unpublished Ph.D. Thesis. University of Dhaka, Dhaka. 282 pp.

WEIMERSKIRCH, H., WILSON, R. P. and LYS, P. 1997. Activity pattern of foraging in the wandering albatross: a marine predator with two modes of prey searching. Marine Ecol. Prog. Series. 151: 245-254.

WILSON, R. P., COOPER, J. and PLOTZ, J. 1992. Can we determine when marine endotherms feed? A case study with seabirds. J. Exp. Biol. 167: 267-275.

YIHUNE, M. and BEKELE, A. 2010. Diet activity of pied kingfisher (Ceryle rudis) in Lake Hora Arsedi, Debrezeit. Ethiop. J. Biol. Sci. 9(2): 117-125. 